\title{
Waste Paper Ash as Partial Replacement of Cement in Concrete
}

\author{
Bikila Meko Kejela \\ Department of Construction Technology and Management, Wolkite University, Wolkite, Ethiopia
}

\section{Email address:}

bikila12@gmail.com

\section{To cite this article:}

Bikila Meko Kejela. Waste Paper Ash as Partial Replacement of Cement in Concrete. American Journal of Construction and Building Materials. Vol. 4, No. 1, 2020, pp. 8-13. doi: 10.11648/j.ajcbm.20200401.12

Received: July 4, 2019; Accepted: January 18, 2020; Published: February 14, 2020

\begin{abstract}
Concrete is one of the versatile and widely used building materials in the world construction industry. Cement being the main binder in concrete, its production process is both uneconomical and environmental unfriendly. In order to alleviate these problems, the use of alternative materials which have lower cost of production, lower emission of $\mathrm{CO}_{2}$, and lower energy consumption, were being implemented. Therefore, the aim of this study is to investigate the effects of waste paper ash as cement replacement material in concrete production. Accordingly, chemical compositions of waste paper ash were investigated and cement was replaced by waste paper ash in a range of $0 \%, 5 \%, 10 \%, 15 \%$, and $20 \%$. To examine the suitability of paper ash for concrete production, its' effect on both fresh and hardened properties of C -25 concrete was studied. From result of this study, it was observed that, the chemical compositions of waste paper ash were not fulfill the requirements of Pozzolanic material. Paper ash has lengthened the setting times of blended cement paste and its normal consistency was increased. The cement paste with replacement up to $10 \%$ showed a normal consistency with in standard range. Workability of the concrete was tested immediately after preparing the concrete mix whereas the compressive strength tests were tested after 7 , and 28 days of curing. The results indicated that workability of concrete containing waste paper ash decreases as the waste paper ash content increases. There is significant improvement in compressive strength of concrete. Replacement of ordinary Portland cement by waste paper ash up to $10 \%$ resulted in a better compressive strength than that of the convectional mix. An enhancement of $5.6 \%$ \& $1.2 \%$ were observed for $5 \%, \& 10 \%$ of replacement respectively. But the compressive strength decreases as the waste paper ash replacement increases over $10 \%$. A highest compressive strength of $37.89 \mathrm{kN} / \mathrm{m}^{2}$ was obtained for concrete containing $5 \%$ of waste paper ash.
\end{abstract}

Keywords: Cement, Concrete, Partial Replacement, Properties of Concrete, Waste Paper Ash

\section{Introduction}

Concrete is one of the most versatile and widely used building materials in the world construction industry. It is a composition of aggregates, a Portland or blended cement, water, and contains other cementitious materials and/or chemical admixtures. It contains some amount of entrapped air and purposely entrained air obtained by use of an admixture or air-entraining cement [1].

The annual production of concrete is rapidly increasing. This is because many developing countries are experiencing rapid urbanization and population growth, making the demand for housing and infrastructure development greater than ever before.

Cement being the main binder in concrete, its production process is both uneconomical and environmental unfriendly. The production of 1 tonne of Portland cement requires 1.5 tonnes of raw material. According to Malhotra, (1988); and Swamy, (1998) the production process of Portland cement is highly energy intensive, consuming 4-7 MJ of fossil fuel energy per $\mathrm{kg},[16,17]$ and releases approximately 1 tonne of carbon dioxide for manufacture of each tonne of Portland cement.

As a result, a requirement for economical and more environmental-friendly leads the way to search for supplementary cementing materials in concrete that can be used as replacement of the normal Portland cement. This can be done by two methods. The first method is using another binding material instead of cement which is not possible right now for unavailability of such a binding materials and the second method is partial replacement of cement by appropriate material. The second method is quite simple because of lots of references are available as well as enough 
suitable materials are also available.

The replacement of cement in concrete by various wastes creates a tremendous saving of energy, costs and also leads to important environmental benefits. As a result, the use of different cement replacing materials has become a common practice in the construction industry.

Supplementary cementitious materials (SCMs) are being utilized as partial replacement of cement. In 2016, Savita D., et al., reviewed the cement replacement materials in concrete and concluded various materials as cement replacing materials. These materials are ceramic waste, paper pulp, Ground granulated blast furnace slag, Silica fume, Hypo sludge, Fly ash, Paper sludge, Waste glass powder, Waste paper sludge ash [2].

According to Ali et al, (2013), more than 450 million tons of paper is produced worldwide per annual and it is expected that the demand for paper will reach 500 million tons per annual by the end of 2020 [10]. And also Asmare, (2015) in his study predicted that the demand of paper to be imported to Ethiopia by the year $2015 / 16$ was $157,956.7$ tons of paper and paper board. This demand of paper was increasing from year to year because of education expansion policies and overall economic development of the country [9].

As it was described by Oriyomi M. O., el at, Paper is an example of valuable materials that can be recycled [3]. Disposable paper available in abundance throughout the world is composed mainly of short, natural, cellulose fibers and is already used in many local raw materials. Waste paper arises from several sources such as newspapers, office and printing papers etc. The chemical composition of paper ash mainly contains $\mathrm{SiO}_{2}(60 \%), \mathrm{CaO}(14 \%), \mathrm{Al}_{2} \mathrm{O}_{3}(2.06 \%)$, and $\mathrm{Fe}_{2} \mathrm{O}_{3}$ $(0.92 \%)$ which are the main essential compounds needed for cement hydration for strength development (Sumit, A. B., et al, 2013).

Due to this pozollanic property, waste paper ash has a possibility to be used as partial replacement of cement in concrete production. So, this study was targeted at investigating the properties of concrete produced by using waste paper ash in order to ascertain their suitability to be used as a cement replacing material in concrete.

\section{Materials and Methods}

The main materials used for this study were Portland cement (OPC), Fine aggregate, Coarse aggregate, waste paper (office copy paper), and Potable water.

\subsection{Materials}

\subsubsection{Cement}

The cement used in this study was Dangote Ordinary Portland Cement (OPC) of grade 42.5, which is obtained commercially. This cement complies with the requirements of Ethiopian Standards, ES C. D5 201.

\subsubsection{Sand}

The river sand, passing through $4.75 \mathrm{~mm}$ sieve was used as a fine aggregate. The sand is free from clay, silt and organic impurities. In order to investigate the properties of sand, different tests were carried out. These tests include gradation and fineness modules, specific gravity and absorption capacity, moisture content, silt content and unit weight. The silt content was found to be $4.54 \%$, which is below the $5 \%$ limit of Ethiopian standard [7]. Fineness modulus is found to be 2.8, which is in the range of ASTM C33 standard 2.3 to 3.1 [5]. The physical properties of sand are compiled in table 1 .

Table 1. Properties of sand.

\begin{tabular}{llll}
\hline No. & Test description & Test result \\
\hline 1 & Silt content & $4.54 \%$ \\
2 & Moisture content & $1.6 \%$ \\
3 & Unit weight (Compacted): & $1437.3 \mathrm{~kg} / \mathrm{m}^{3}$ \\
4 & Absorption capacity & & $2.04 \%$ \\
& & Bulk & 2.65 \\
5 & Specific gravity: & Bulk (SSD) & 2.70 \\
& & Apparent & 2.80 \\
6 & Fines Modules & & 2.8 \\
\hline
\end{tabular}

\subsubsection{Coarse Aggregates}

Coarse aggregates used in this research were crushed granite, supplied from a local quarry, with maximum size of $20 \mathrm{~mm}$. In a similar routine like the fine aggregate, the coarse aggregate was tested for its physical requirements such as gradation, fineness modulus, specific gravity, bulk density and presented in the following table 2 .

Table 2. Properties of coarse aggregate.

\begin{tabular}{|c|c|c|c|}
\hline No. & \multicolumn{2}{|c|}{ Test description } & Test result \\
\hline 1 & \multicolumn{2}{|c|}{ Maximum size } & $20 \mathrm{~mm}$ \\
\hline 2 & \multicolumn{2}{|c|}{ Moisture content } & $1 \%$ \\
\hline & \multicolumn{2}{|c|}{ Unit weight compacted } & $1591.35 \mathrm{~kg} / \mathrm{m}^{3}$ \\
\hline 4 & \multicolumn{2}{|c|}{ Absorption capacity } & $1 \%$ \\
\hline 5 & $\begin{array}{l}\text { Specific } \\
\text { gravity: }\end{array}$ & $\begin{array}{l}\text { Bulk } \\
\text { Bulk (SSD) } \\
\text { Apparent }\end{array}$ & $\begin{array}{l}2.77 \\
2.80 \\
2.86\end{array}$ \\
\hline
\end{tabular}

\subsubsection{Waste Paper Ash}

Waste paper was collected from different office and burned using incinerator at a temperature of $850^{\circ} \mathrm{C}$ to avoid formation of crystalline ash which is less reactive to lime. Burned powder was then sieved using sieve size of $7.4 \mu \mathrm{m}$. According to A. M. Neville there is no simple relation between strength and cement particle size [8]. So, particle size distribution analysis was neglected.

\subsection{Mix Design and Sample Production}

ACI method of mix design [4] was used in designing the mixes based on collected data. The mix was prepared for C-25 Concrete with Design Strength (target mean strength) of 33.5MPa. The mixing proportion was found to be $1: 2.35: 3$. After determining the relative amount of materials to be used for the specimens, waste paper ash is thoroughly blended with cement at $5 \%, 10 \%, 15 \%$, and $20 \%$. Then the aggregates and sands are added and mixed in dry for one minute. Later water was added and, all the materials were mixed for another two minutes. Finally, the prepared specimens was submerged in curing tanker and cured for an age of 7days, and 28days at 
room temperature according to ASTM C192 Standard [6].

\section{Results and Discussion}

\subsection{Chemical Compositions of Waste Paper Ash}

The chemical compositions of materials are very crucial in determining their suitability as Supplementary cementitious materials (SCMs). So, the chemical composition of waste paper ash was studied in Geological survey of Ethiopia and compiled in Table 3 based on the finding of laboratory investigation.

Table 3. Chemical composition of waste paper ash.

\begin{tabular}{ll}
\hline Chemical Composition (\%) & Waste paper Ash \\
\hline $\mathrm{SiO}_{2}$ & 29.20 \\
$\mathrm{Al}_{2} \mathrm{O}_{3}$ & 2.65 \\
$\mathrm{CaO}$ & 50.88 \\
$\mathrm{Fe}_{2} \mathrm{O}_{3}$ & 1.74 \\
$\mathrm{MgO}$ & 0.86 \\
$\mathrm{Na}$ & 0.30 \\
$\mathrm{~K}_{2} \mathrm{O}$ & $<0.01$ \\
$\mathrm{MnO}$ & $<0.01$ \\
$\mathrm{P}_{2} \mathrm{O}_{5}$ & 0.67 \\
$\mathrm{TiO}_{2}$ & $<0.01$ \\
$\mathrm{H}_{2} \mathrm{O}$ & 0.62 \\
$\mathrm{LOI}$ & 12.52 \\
$\mathrm{SO}_{3}$ & 0.51 \\
\hline
\end{tabular}

From these results, the chemical compositions which are $\mathrm{SiO}_{2}+\mathrm{Al}_{2} \mathrm{O}_{3}+\mathrm{Fe}_{2} \mathrm{O}_{3}=33.59 \%$ is less than $70 \%$. According to ASTM C- 618 specification, the waste paper ash did not fulfill the requirements of Pozzolanic material.

According to this finding the principal constituents present in Waste Paper Ash are lime $(\mathrm{CaO})$ and silica $\left(\mathrm{SiO}_{2}\right)$. The chemical activity of admixtures in cement is dependent essentially on their lime, silica and alumina contents which are the main essential compounds needed for cement hydration for strength development.

The silica content of paper ash was higher than that of OPC. This gives an indication that the paper ash would produce satisfactory results in terms of strength. However, the alumina content was very low (2.65\%). Alumina makes little direct contribution to the strength of Portland cement. Iron oxide content (1.74) which is also low has no effect on cement but acts as flux to aid cement and gives the grey color. The other minor constituents like $\mathrm{TiO}_{2}, \mathrm{MnO}_{2}$ and $\mathrm{P}_{2} \mathrm{O}_{3}$ were less than $1 \%$ and have no effect on strength and properties of cement products.

A number of published literatures have reported chemical composition of paper pulp. In 2006, Sumit, et al, (2013) has studied elemental analysis of waste paper pulp and Paper pulp mainly contains $\mathrm{Si}(60 \%)$ and $\mathrm{Ca}(14 \%)$ [11]. But in this study paper ash mainly contains $\mathrm{Si}(29.20 \%)$ and $\mathrm{Ca}(50.88 \%)$ which is different from previous studies.

The loss on ignition (LOI) value for the paper ash was found to be $12.52 \%$ which was slightly higher than that specified by the standard $(10 \%)$. The loss on ignition shows the extent of carbonation and hydration of free lime and free magnesia due to the exposure of cement to the atmosphere. The maximum loss on ignition (at $1000^{\circ} \mathrm{C}$ ) permitted by $\mathrm{BS}$ EN 197-1: 2000 is 5 percent [14] and by ASTM C 150-07 is 3 percent except for Type I cement (2.5 per cent) [15]; 4 per cent is acceptable for cements in the tropics.

\subsection{Setting Times of the Blended Paste}

The setting times of the blended paste containing waste paper ash are given in Table 4. The set time was determined from an average of three sets of samples for each type of blended cement pastes.

Table 4. Setting time of blended cement pastes.

\begin{tabular}{llll}
\hline No & \% of replacement & $\begin{array}{l}\text { Initial setting } \\
\text { Time (Min.) }\end{array}$ & $\begin{array}{l}\text { Final setting Time } \\
\text { (Min.) }\end{array}$ \\
\hline 1 & $0 \%$ & 176 & 301.2 \\
2 & $5 \% \mathrm{WPA}$ & 208 & 339.6 \\
3 & $10 \% \mathrm{WPA}$ & 220 & 354 \\
4 & $15 \% \mathrm{WPA}$ & 225 & 360 \\
5 & $20 \% \mathrm{WPA}$ & 250 & 390 \\
\hline
\end{tabular}

It was observed that the common effect of the paper ash has lengthened the setting times of blended cement paste. This due to the reaction which is responsible for the setting of cement is the reaction of $\mathrm{C}_{3} \mathrm{~A}$ with both water and gypsum $\left(\mathrm{CaSO}_{4} \cdot 2 \mathrm{H}_{2} \mathrm{O}\right)$ but the amount of $\mathrm{C}_{3} \mathrm{~A}$ found in paper ash is lower, when compared with that of OPC. So this lower amount of $\mathrm{C}_{3} \mathrm{~A}$ retarded setting time of blended cement paste.

The Ethiopian standard limits the initial setting time of cement not to be less than 45 minutes and the final setting time not to exceed $10 \mathrm{hrs}$. The results for the setting time indicated that addition of waste paper ash retarded the setting; however, this retardation was within limits as specified by the Ethiopian standard.

\subsection{Consistency of Blended Cement Paste}

A certain minimum quantity of water is required to be mixed with cement, so as to complete chemical reaction between water and cement. Less water than this quantity would not complete chemical reaction thus resulting in reduction of strength and more water would increase water cement ratio and reduce its strength. So, correct proportion of water to cement is required to be known to achieve proper strength while using cement in structure. In order to get proper amount of water normal consistency test of blended cement pastes was carried out. The normal consistency of blended pastes containing waste paper ashes are shown in figure 1 .

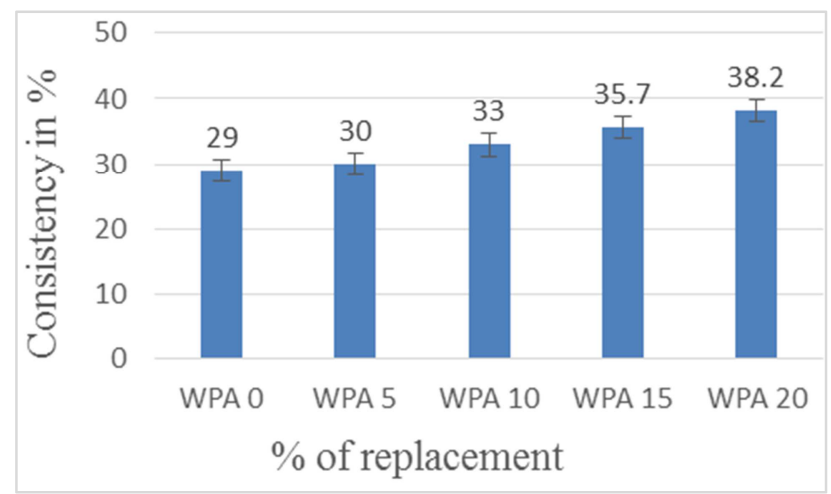

Figure 1. Consistency of Blended cements Paste. 
The control paste or the paste without waste paper ash had normal consistency of $29 \%$. All of the pastes containing waste paper ash showed normal consistency higher than the control paste. The usual range of water to cement ratio for normal consistency is between $26 \%$ and $33 \%$ [11]. The pastes with replacement up to $10 \%$ showed a consistency with in this range, however, after $10 \%$ replacement the results showed higher values of consistency.

\subsection{Workability of Concrete}

In order to determine the workability of the fresh concrete the slump test was conducted according to ASTM C 143. Slump test is conducted on fresh concrete for all percentage of waste paper ash replacement. The slump values of all the mixtures are presented in Figure 2 below.

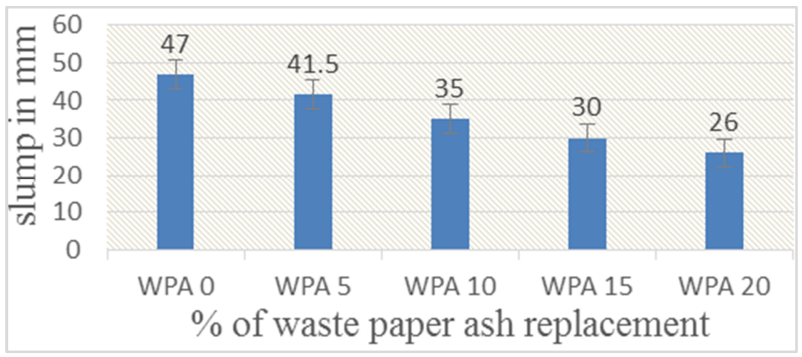

Figure 2. Workability of concrete.

These results indicate that, the slump decreased with the increase in waste paper ash content. This effect can be attributed to the fact that paper ash has high water absorption capacity as compared to cement and thus the content of water in the mix is reduced, hence less workable concrete is produced. The second reason is due to its' lower density of paper ash giving it a higher porosity resulting in higher water demand. Even though the slump value is decreased as percentage of waste paper ash is increased, until the amount of percentage is became $20 \%$ the slump value is within the specified limit, which is $30-50$. The highest slump was seen for the control concrete mix.

The effect of replacing Portland cement with paper pulp on the workability of concrete has been done by a number of preceding researchers and concluded that the workability was decreased when a higher amount of paper ash content was included. As Sumit, et al, (2013) reported in his work, the slump increased up to $5 \%$ replacement of cement, above $5 \%$ the slump decreased as the paper pulp content in the concrete mixtures was increased [11].

\subsection{Compressive Strength of Concrete}

Compressive strength test was conducted on hardened concrete using a compression testing machine of $2000 \mathrm{KN}$ capacity. Three cubes $(150 \mathrm{~mm}$ X $150 \mathrm{~mm}$ X 150mm) were casted for each percentage replacements of cement by waste paper ash and cured for 7 days $\& 28$ days. After the successful curing of concrete, all specimens are tested in compression testing machine by applying compressive load. Figure 3 and table 5 shows the measured compressive strengths of concrete cubes with various content of paper ash at age of $7^{\text {th }}$ and $28^{\text {th }}$ days.

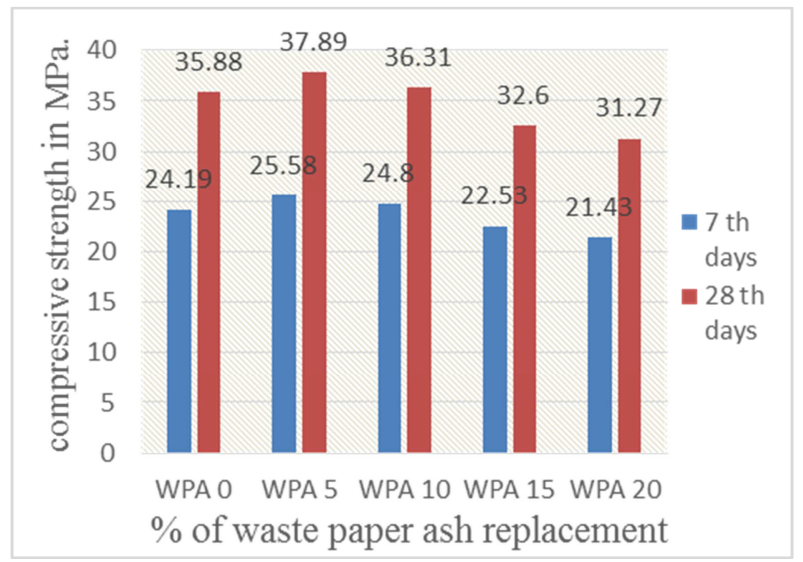

Figure 3. $7^{\text {th }}$ and $28^{\text {th }}$ day compressive strength.

Based on these experimental results the strength properties of concrete are increasing as percentage of paper ash increases up to $10 \%$, later the strength is decreasing when compared with the control specimen.

An improvement of $5.6 \%$ \& $1.2 \%$ were observed for $5 \%$ and $10 \%$ replacement, when compared with 28-day compressive strength of Control mix which made with ordinary Portland cement. This due to the higher amount of silica found in paper ash than cement. However, the degree of improvement in strength appeared to be highly dependent on the cement replacement level. It observed that the concretes with $15 \%$ and $20 \%$ waste paper ash had shown reduction of compressive strength.

The effects of paper ash on the compressive strength of concrete did not vary from the findings of previous researchers. A number of published literature [Sumit, et al, 2013 and H. Yun et al, 2007] reported similar observations.

In 2007, H. Yun et al. worked on mechanical properties of papercrete concluded that the average compressive strength which includes 5\% paper-cement replacement ratio was 34 $\mathrm{MPa}$ [12].

Also Sumit, et al, (2013) in their studies on Utilization of Waste Paper Pulp by Partial Replacement of Cement in Concrete, concluded that, the compressive, splitting tensile and flexural strength increased up to $10 \%$ addition of waste paper pulp and further increments in replacement of cement gradually reduces the strengths of concrete [11].

Table 5. Compressive Strength of Concrete.

\begin{tabular}{|c|c|c|c|c|c|c|}
\hline \multirow{2}{*}{$\mathbf{S} / \mathbf{N}$} & \multirow{2}{*}{ Mix code } & \multirow{2}{*}{$\%$ of replacement } & \multicolumn{4}{|c|}{ Average Compressive strength in $\mathrm{N} / \mathrm{mm} 2$} \\
\hline & & & $7^{\text {th }}$ day & Increment in \% & $28^{\text {th }}$ day & Increment in \% \\
\hline 1 & WPA 0 & $\mathrm{OPC}$ & 24.19 & & 35.88 & \\
\hline 2 & WPA 5 & $95 \% \mathrm{OPC}+5 \% \mathrm{WPA}$ & 25.58 & $5.43 \%$ & 37.89 & $5.6 \%$ \\
\hline 3 & WPA 10 & $90 \% \mathrm{OPC}+10 \% \mathrm{WPA}$ & 24.8 & 2.52 & 36.31 & $1.2 \%$ \\
\hline
\end{tabular}




\begin{tabular}{lllllll}
\hline \multirow{2}{*}{ S/N } & \multirow{2}{*}{ Mix code } & \multirow{2}{*}{ \% of replacement } & \multicolumn{4}{l}{ Average Compressive strength in N/mm2 } \\
\cline { 4 - 7 } & & & $\mathbf{7}^{\text {th }}$ day & Increment in \% & $\mathbf{2 8}^{\text {th }}$ day & Increment in \% \\
\hline 4 & WPA 15 & $85 \% \mathrm{OPC}+15 \%$ WPA & 22.53 & $-6.86 \%$ & 32.60 & $-9.14 \%$ \\
5 & WPA 20 & $805 \% \mathrm{OPC}+20 \% \mathrm{WPA}$ & 21.43 & $-11.40 \%$ & 31.27 & $-12.84 \%$ \\
\hline
\end{tabular}

\subsection{Density of Concrete}

The weights and the dimension of the concrete cubes are measured just before testing them for the compressive strength after curing for 7 , and 28 days. The samples have similar volume of $0.00338 \mathrm{~m}^{3}$. Their unit weight was measured and compiled in table 6 below.

Table 6. Unit weight of concrete.

\begin{tabular}{llll}
\hline S. $\mathbf{N}$ & \% of replacement & $\begin{array}{l}\text { Unit wt. } \\
\left(\mathbf{k g} / \mathbf{m}^{\mathbf{3}}\right)\end{array}$ & Reduction in (\%) \\
\hline 1 & OPC & 2444.44 & \\
2 & $95 \% \mathrm{OPC}+5 \% \mathrm{WPA}$ & 2419.95 & $1 \%$ \\
3 & $90 \% \mathrm{OPC}+10 \% \mathrm{WPA}$ & 2392.88 & $1.12 \%$ \\
4 & $85 \% \mathrm{OPC}+15 \% \mathrm{WPA}$ & 2359.79 & $1.4 \%$ \\
5 & $805 \% \mathrm{OPC}+20 \% \mathrm{WPA}$ & 2311.52 & 2.05 \\
\hline
\end{tabular}

The results of this study revealed that, paper ash reduces the hardened density of concrete as its percentage in the mix increases. The percentage of reduction was increased as amount of paper ash increases. But these densities of the concrete fall within the range of $2200-22400 \mathrm{~kg} / \mathrm{m}^{3}$, which is considered to be of normal weight concrete [1].

The above findings are not different from the preceding studies. H. Yun et al, (2007) studied the physical properties of the Papercrete and concluded that the density of papercrete was decreased when the replacement ratio of waste paper of papercrete increased [12]. The physical properties of papercrete were also reported by Shivangni Khandelwal et al, (2015). They concluded that, the density of the papercrete has a tendency of decrease as a higher waste paper was included [13].

\section{Conclusion}

The results of this study reveal, Waste paper ash cannot be as classified as pozzolanic material. As prescribed by ASTM C 618 , in order to classify particular material as pozzolanic materials, its chemical composition $\left(\mathrm{SiO}_{2}+\mathrm{Al}_{2} \mathrm{O}_{3}+\mathrm{Fe}_{2} \mathrm{O}_{3}\right)$ have to be greater than $70 \%$ but that of paper ash is less than $70 \%$.

Higher replacement of cement by waste paper ash resulted in higher normal consistency (implying higher water demand for certain workability) and longer setting time. Workability of the concrete containing waste paper ash decreases as the waste paper ash content increases.

Significant enhancement was seen in compressive strength of concrete. Replacement of ordinary Portland cement with up to $10 \%$ of waste paper ash results in a better compressive strength than that of the conventional concrete for all curing ages. A highest compressive strength of $37.89 \mathrm{kN} / \mathrm{m}^{2}$ was obtained for concrete containing $5 \%$ of waste paper ash. But beyond $10 \%$ of replacement, there is a gradual reduction in compressive strength.

The density of the concretes containing waste paper ash has shown a reduction. It was found that a reduction of unit weight up to $2.05 \%$ was observed when $20 \%$ of the cement was replaced by waste paper ash.

\section{References}

[1] Kosmatka, S. H., Kerkhoff, B., Panarese, W. C. (2003). Design and Control of Concrete Mixtures (14th edition ed.). Skokie, Illinois, USA,: Portland Cement Association.

[2] Savita, D., Nitish, G., Mahipal, N. M., Balveer, M., Mahesh, V. (2016). Review on Cement Replacement in Construction Industry. SSRG International Journal of Civil Engineering, 3 (5), 68-71.

[3] Oriyomi, M. O., Oluwatobi, J. I. (2014). Assessment of the Suitability of Paper Waste as an Engineering. Material Engineering, Technology \& Applied Science Research, 4 (6), 724-727.

[4] ACI Committee, Building Code Requirements for Structural Concrete (ACI 318-08). American Concrete Institute, 2008.

[5] American Society for Testing and Materials, "Standard Specification for Concrete Aggregates," in ASTM Standards, vol. 04, West Conshohocken, PA: ASTM International, 2001.

[6] American Society for Testing and Materials, "Standard Practice for Making and Curing Concrete Test Specimens in the," in ASTM Standards, vol. 04, Farmington, 2000, pp. 1-8.

[7] Ministry of Urban Development Housing and Construction, Standard Technical Specifications for Building Works. Addis Ababa, 2014.

[8] A. M. Neville, Properties of concrete, 5th ed. Trans-Atlantic Publications, Inc., 2011.

[9] Asmare, G. (2015). Pulp Production from Cotton Stalks using Kraft Pulping. Addis Ababa: Addis Ababa University.

[10] Ali, A., Hashmi, H. N. \& Baig, N. (2013), "Treatmentof the paper mill effluent - A review", Annals of Faculty Engineering Hunedoara - International Journal of Engineering 11 (3), 337-340.

[11] Sumit, A. B., S. P. Raut.,. (2013). Utilization of Waste Paper Pulp by Partial Replacement of Cement in Concrete. International Journal of Engineering Research and Applications (IJERA), Vol. 1, pp. 300-309.

[12] Yun, H., Jung, H., Choi, C. (2007). Mechanical properties of papercrete containing waste paper. Korea: Architectural Institute of Korea.

[13] Shivangni, K., Kishan, L. P., and Mukul, k. (2015). Review on papercrete. IJCRD, 4 (6).

[14] European Standard, "Composition, specifications and conformity criteria for common cements," in BS EN standards, Brussels, 2000. 
[15] American Society for Testing and Materials "Standard Specification for Portland Cement," in ASTM standards, Washington, D. C., 2007.

[16] Malhotra VM., (1988). Use of fly ash, slag and condensed silica fume in North America and Europe. In: Ryan WG, editor. Proc concrete workshop 88. Int workshop on the use of fly ash, slag, silica fume and other siliceous materials in concrete July 4-6, Sydney, Australia; 23-55.
[17] Swamy RN., (1998). Designing concrete and concrete structures for sustainable development. In: Malhotra VM, editor. Proc sixth international conference on fly ash, slag, silica fume and other natural pozzolans in concrete. Bangkok, Thailand; ACI SP-178; 1: 245-55. 